\title{
Pembelajaran Luas Daerah Persegi Panjang Berdasarkan Standar Pengajaran National Council of Teachers of Mathematics (NCTM) Untuk Meningkatkan Pemahaman Siswa Kelas III SDN Dinoyo I Malang
}

\author{
Ika Ratih Sulistiani \\ Program Studi PGMI, Universitas Islam Malang, Jl. Mayjen Haryono No.193, Dinoyo, Kec. Lowokwaru, \\ Kota Malang, Jawa Timur 65144, Indonesia \\ Korespondensi; Email: mynurika@yahoo.com
}

\begin{abstract}
Abstrak
Penelitian ini menganalisis masalah yang dihadapi oleh siswa dari SD Negeri 1 Dinoyo Malang dalam kesulitan memahami daerah persegi panjang. Menurut diskusi dengan guru mereka, ditemukan bahwa pembelajaran masih belum memberikan lebih banyak kesempatan kepada siswa untuk mengetahui konsep wilayah persegi panjang dengan cara mereka sendiri. Selain itu, beberapa siswa sulit dalam memecahkan masalah sehari-hari yang berisi model daerah persegi panjang. Oleh karena itu perlu upaya besar untuk membangun pemahaman siswa pada konsep wilayah persegi panjang. Salah satu upaya yang guru dapat lakukan adalah mencoba menerapkan pembelajaran berdasarkan standar proses NCTM. Tujuan dari penelitian ini adalah untuk mendeskripsikan pembelajaran daerah persegi panjang berdasarkan standar proses NCTM yang diyakini dapat membantu pemahaman siswa. Proses pembelajaran dilakukan melalui lima tahapan yang masing-masing menggunakan Lembar Kerja Siswa. Imbal hasil penelitian: (1) peningkatan kualitas kegiatan mahasiswa dari $85 \%$ (pada siklus I) menjadi 90\% (pada siklus kedua), (2) pengibaran pemahaman siswa dari 73,5\% (pada siklus pertama) untuk $82,5 \%$ (pada siklus kedua), dan (3) respon yang baik dari siswa.
\end{abstract}

Kata Kunci: NCTM; Luas Persegi Panjang

\begin{abstract}
This research is analyzing the problem that faced by students of SD Negeri 1 Dinoyo Malang in difficulty of understanding rectangle area. According to the discussion with their teacher, it is found that the learning still not gives more chance to the students to find out the concept of rectangle area with their own ways. Moreover, some students are difficult in solving daily problem containing model of rectangle area. Therefore it needs great effort to build students understanding on the concept of rectangle area. One of effort that teacher can do is trying to apply the learning based on process standard NCTM. The aim of this research is to describe the learning of rectangle area based on process standard NCTM that believed can help student understanding. The learning process is done through five phases that each using Student Worksheet. The research yields: (1) the increasing of student activities quality from $85 \%$ (in the first cycle) to $90 \%$ (in the second cycle), (2) the raising of student understanding from $73.5 \%$ (in the first cycle) to $82.5 \%$ (in the second cycle), and (3) good response from students.
\end{abstract}

Keywords: NCTM; Rectangle Area

\section{Pendahuluan}

Pada dasarnya geometri mempunyai peluang lebih besar untuk dipahami siswa daripada cabang matematika yang lain, karena geometri adalah satu-satunya cabang matematika yang sudah dikenal siswa sejak sebelum masuk sekolah. Ide-ide tentang geometri yang sudah dikenal siswa tersebut diantaranya siswa mengenal berbagai macam bentuk geometri mulai dari bangun datar hingga bangun ruang. Namun kenyataannya, masih banyak siswa yang mengalami kesulitan dalam mempelajari 
geometri dan respon siswa terhadap pembelajaran geometri pada umumnya tidak baik. Siswa merasa tidak senang dalam belajar geometri dan siswa menganggap bahwa pembelajaran matematika khususnya geometri merupakan sesuatu yang membosankan (Nu'man, 2006: 2).

Kesulitan siswa belajar geometri terjadi diantaranya pada pokok bahasan bangun segiempat. Sunismi (2001:1) menyatakan bahwa salah satu topik yang sulit dipahami siswa adalah bangun segiempat. Alayubi (2005:120) dalam penelitiannya menemukan bahwa siswa cenderung menghafal sifat-sifat bangun persegi dan persegipanjang. Selanjutnya Numan (2006:113) melaporkan bahwa masih ada siswa yang mengalami kesulitan dalam mengungkapkan pengertian bangun datar dan sifat- sifat yang sama antar bangun datar.

Beberapa temuan tentang kesulitan siswa memahami geometri tersebut mengakibatkan hasil belajar siswa menjadi rendah. Sudarman (2000:3) menyatakan bahwa diantara berbagai cabang matematika, pemahaman terhadap geometri menempati posisi yang paling memprihatinkan, yaitu paling rendah prestasi hasil belajarnya. Sependapat dengan hal tersebut Madja (2002:3) menyatakan bahwa hasil tes geometri masih kurang memuaskan (lebih rendah) jika dibandingkan dengan hasil tes materi matematika yang lain.

Salah satu faktor penyebab rendahnya prestasi dan minat belajar geometri selama ini, salah satunya dikarenakan oleh pembelajaran yang dilaksanakan oleh guru yang masih bersifat konvensional. Schoenfeld (dalam Yuwono, 2001:8) menyatakan bahwa pembelajaran matematika secara konvensional mengakibatkan siswa hanya menghafal dan bekerja secara prosedural dan memahami matematika tanpa penalaran. Senada dengan pendapat tersebut Ratumanan (2000:431) menyatakan bahwa siswa sering diposisikan sebagai orang yang tidak tahu apa-apa yang hanya menunggu dan menyerap apa yang diberikan guru, akibatnya siswa pasif dan gurulah yang aktif. Pembelajaran konvensional cenderung mengacu pada pandangan behavioristik sudah saatnya dikaji ulang atau bahkan ditinggalkan sama sekali (Hudojo, 1998:5). Sudah saatnya siswa diberi kesempatan seluas-luasnya untuk mengembangkan diri. Peran guru sebagai pemberi ilmu, sudah saatnya berubah menjadi fasilitator yang menfasilitasi siswa untuk dapat belajar dan mengkonstruksi pengetahuan sendiri sehingga siswa akan merasa senang terhadap pembelajaran (Hudojo, 1998:5).

Berdasarkan wawancara dengan seorang guru matematika, peneliti mendapatkan informasi bahwa siswa kelas III SDN Dinoyo 1 Malang mengalami kesulitan dalam memahami luas bangun datar persegi panjang. Kesulitan tersebut sebagai berikut: (1) siswa sulit menjelaskan definisi luas persegi panjang, (2) siswa sulit menentukan dan menyebutkan sifat-sifat bangun persegi panjang, (3) siswa cenderung menghafal definisi luas dan sifat-sifat bangun persegi panjang dari buku atau dari penjelasan guru, (4) siswa kesulitan untuk mengerjakan soal yang berkaitan dengan soal luas persegi panjang yang berbentuk soal cerita. Berdasarkan wawancara dengan beberapa siswa, penulis menemukan bahwa jika siswa ditanya berapa luas persegi panjang dengan diketahui panjangnya $p$ dan lebarnya I, sebagian besar siswa langsung menjawab dengan menggunakan rumus $L=p \times I$. Tetapi jika ditanya mengapa rumus luas persegi panjang $\mathrm{L}=\mathrm{p} \times \mathrm{I}$, siswa tidak dapat segera memberikan jawaban.

Pada studi awal peneliti di SDN Dinoyo 1 Malang, peneliti menanyakan metode pembelajaran yang dilakukan guru matematika untuk mengajarkan materi luas daerah persegi panjang dan respon siswa selama pembelajaran matematika khususnya luas daerah persegi panjang. Guru menyampaikan bahwa pembelajaran luas daerah persegi panjang langsung dengan memberikan rumus, latihan, dan soal. Rumus luas daerah persegi panjang hanya sekedar diberikan oleh guru dan siswa menghafal. Hal tersebut mengakibatkan siswa kurang aktif dalam pembelajaran karena siswa hanya bekerja secara prosedural dan memahami matematika tanpa penalaran dan siswa merasa bosan selama pembelajaran.

Berdasarkan uraian di atas, kondisi pembelajaran seharusnya perlu mempertimbangkan untuk menggunakan pendekatan yang dapat memberikan kesempatan kepada siswa untuk mengkonstruksi sendiri pengetahuannya. Di samping mampu meningkatkan prestasi belajar juga memperdulikan skemata siswa serta dapat memberikan respon yang baik kepada siswa. Salah satu cara untuk membantu siswa dalam belajar matematika agar menjadi aktif dalam belajarnya adalah pembelajaran matematika menurut standar NCTM tahun 2000.

Standar pengajaran menurut NCTM terdiri dari 6 standar yang disusun dalam empat komponen, yaitu (1) tugas, (2) wacana, (3) lingkungan belajar, dan (4) analisis. Tugas yang diberikan berupa proyek, pertanyaan, masalah, konstruksi, aplikasi dan latihan-latihan yang mengikutsertakan siswa. Wacana meliputi cara mempresentasikan, berpikir, berbicara, menyetujui dan tidak menyetujui yang dilakukan oleh guru dan siswa dalam membicarakan penyelesaian suatu tugas. Dalam kegiatan 
pemberian tugas dan pelaksanaan, wacana guru harus menciptakan lingkungan belajar yang membantu perkembangan kemampuan matematika siswa. Analisis adalah refleksi sistematis yang dilakukan oleh guru untuk memonitor kegiatan di kelas tentang cara pemberian tugas yang, wacana dan lingkungan yang mempercepat perkembangan kemampuan matematika setiap siswa.

Beberapa penelitian menyatakan bahwa pembelajaran berdasarkan standar NCTM efektif untuk membantu siswa dalam memahami materi matematika. Kusumawati (2005: 103) menyatakan bahwa pembelajaran dengan menerapkan standar NCTM bisa membantu siswa dalam memahami materi kubus dan balok. Senada dengan pernyataan di atas, Sarjiman (2003: 78) menyatakan pembelajaran dengan menerapkan standar NCTM bisa meningkatkan hasil belajar siswa dalam materi pecahan.

Berdasarkan uraian yang dikemukakan di atas peneliti hendak meningkatkan pemahaman matematika pada materi luas daerah persegi panjang siswa kelas III SDN Dinoyo I Malang melalui penerapan pembelajaran menurut standar proses National Council of Teachers of Mathematics (NCTM).

\section{Metode Penelitian}

Penelitian ini dimaksudkan sebagai usaha membantu siswa untuk meningkatkan pemahaman konsep luas daerah persegi panjang dengan berdasarkan standar pengajaran NCTM. Dalam usaha meningkatkan tersebut, peneliti berperan sebagai pelaksana pembelajaran. Oleh sebab itu, rancangan penelitian yang cocok dengan tujuan tersebut adalah penelitian tindakan kelas.

Lokasi penelitian ini adalah SDN Dinoyo I Malang. SD ini dipilih karena masih banyak yang mengalami kesulitan dalam memahami konsep luas daerah persegi panjang. Selain itu, di SD ini belum pernah dilakukan penelitian mengenai pembelajaran dengan berdasarkan standar pengajaran NCTM.

Sumber data dalam penelitian ini adalah siswa kelas III SDN Dinoyo I Malang. Sedangkan subyek wawancara terdiri dari 5 siswa yang terdiri dari 1 siswa berkemampuan tinggi, 3 siswa berkemampuan sedang, dan 1 siswa berkemampuan rendah. Pengambilan 5 subyek dengan kriteria tinggi, sedang, dan rendah berdasarkan skor tes awal dan dikonsultasikan dengan guru matematika agar subyek yang terpilih muadah untuk diajak berkomunikasi.

Data yang akan dikumpulkan dalam penelitian ini meliputi hasil tes, hasil wawancara, hasil observasi, dan hasil catatan lapangan. Sesuai data yang dikumpulkan dalam penelitian, maka teknik pengumpulan data dalam penelitian ini meliputi (1) tes, (2) wawancara, (3) observasi, dan (4) catatan lapangan.

Analisis data dalam penelitian ini dilakukan setiap kali setelah pemberian suatu tindakan. Teknik analisis data yang akan digunk makan adalah model alir yang dikemukakan Miles dan Huberman (1992:18) yang meliputi kegiatan (1) mereduksi data (2) menyajikan data, dan (3) menarik kesimpulan serta verifikasi.

\section{Hasil dan Pembahasan}

Penelitian ini dilakukan dalam 2 siklus. Masing-masing siklus dilakukan dalam tiga kali pertemuan. Siklus I adalah pembelajaran untuk menemukan luas daerah persegi panjang. Siklus II adalah pembelajaran untuk mengaplikasikan rumus luas daerah persegi panjang dalam kehidupan sehari-hari.

Selama pelaksanaan pembelajaran dapat diperoleh beberapa data sebagai berikut:

1. Pemahaman siswa terhadap materi sangat baik. Setelah diadakan wawancara tentang hasil tes akhir, setiap siswa yang merupakan subjek wawancara mampu menjelaskan dengan baik hasil pekerjaannnya.

2. Siswa sangat aktif pada diskusi dalam kelompok. Menurut siswa, dengan belajar berkelompok, mereka bisa bertanya kepada teman satu kelompok jika mengalami kesulitan.

3. Siswa merasa senang dalam belajar dengan LKS dan media yang diberikan. 
4. Dari wawancara terlihat bahwa siswa lebih senang menemukan sendiri luas persegi panjang dengan kegiatan awal menempatkan persegi-persegi satuan.

Hasil tes akhir masing-masing siklus menunjukkan bahwa presentase ketuntasan hasil belajar siswa meningkat $5 \%$ dari siklus I sebesar $85 \%$ menjadi $90 \%$ pada siklus II. Presentase pemahaman siswa juga mengalami peningkatan, dari kategori baik menjadi kategori sangat baik yaitu $73.5 \%$ menjadi $82.5 \%$.

Untuk menjaring data, peneliti juga melakukan wawancara. Setelah pelaksanaan proses belajar mengajar, peneliti mengadakan wawancara dengan subyek wawancara yang berjumlah 5 siswa. Berdasarkan hasil wawancara, semua subyek wawancara menyatakan bahwa mereka senang mengikuti pembelajaran karena dapat bekerja sama dan menemukan sendiri rumus luas daerah persegi panjang. Subyek juga menyatakan sangat senang bekerja menggunakan alat peraga dan mereka dapat memahami materi dan mengaplikasikannya pada soal-soal.

Pembelajaran luas daerah persegi panjang dalam penelitian ini dilaksanakan dalam 2 (dua) siklus. Siklus pertama untuk menemukan luas daerah persegi panjang, pertemuan kedua untuk mengaplikasikan rumus luas daerah persegi dalam kehidupan sehari-hari.

Pembelajaran pada setiap pertemuan secara umum terbagi dalam tiga tahap, yaitu tahap awal, tahap inti, dan tahap akhir. Tahap awal adalah tahap untuk mempersiapkan siswa agar benarbenar siap untuk belajar. Menyiapkan siswa meliputi persiapan fisik dan persiapan mental. Persiapan fisik meliputi menyediakan semua sarana yang diperlukan lembar kerja siswa, membagi siswa dalam kelompok-kelompok. Sedangkan persiapan mental meliputi kegiatan menyampaikan salam, bertanya kabar, menyampaikan indikator, memotivasi siswa tentang pentingya materi luas daerah persegi panjang, dan mengingatkan materi prasyarat.

Siswa yang telah siap belajar baik secara fisik dan mental belajar lebih banyak daripada siswa yang tidak siap. Hal ini sesuai dengan pendapat Hudojo (1988) bahwa belajar harus menyadari betapa pentingnya menimbulkan motivasi belajar peserta didik, sebab peserta didik yang memiliki motivasi belajar akan lebih siap daripada peserta didik yang tidak diberi motivasi belajar. Orton (1992) juga berpendapat bahwa siswa yang telah siap untuk belajar akan memperoleh hasil belajar yang baik dari pada siswa yang tidak siap.

Penggunaan LKS pada saat siswa melakukan diskusi bertujuan agar terjadi proses bimbingan yang dilakukan oleh siswa yang lebih mampu menyelesaikan masalah kepada siswa yang kurang mampu. Hal ini sesuai dengan pendapat Suparno (1997) bahwa interaksi sosial siswa sangat penting artinya suatu interaksi sosial dengan orang lain yang mempunyai pengetahuan lebih baik.

Saat bekerja dalam tahap inti siswa berada dalam kelompok yang terdiri dari 5 siswa. Penggunaan belajar secara kelompok dalam penelitian ini memberikan banyak keuntungan bagi siswa. Siswa dapat saling berdiskusi untuk menyelesaikan pekerjaan kelompoknya, seperti ketika menyelesaikan persoalan yang memuat model penemuan rumus luas daerah persegi panjang. Masing-masing anggota kelompok saling memberikan bantuan dan masukan dalam meningkatkan pemahamannya tentang suatu konsep. Misalnya ketika mengaitkan tentang konsep penemuan rumus luas dan konsep apliklasinya, ada di antara anggota kelompok yang lupa tentang konsep luas persegi panjang, maka anggota yang lain mengingatkannya. Anggota kelompok yang kurang mampu bertanya kepada anggota kelompok yang lebih mampu mengenai hal-hal yang belum dipahami. Sedangkan siswa yang lebih mampu telah bertambah pemahamannya melalui proses menjelaskan kepada anggot yang kurang mampu. Hal ini sesuai dengan pendapat Vygotsky (1986) anak berada pada zona perkembangan proximal bahwa selain guru, teman sebaya yang lebih pintar juga akan memberikan bantuan kepada siswa yang berkemampuan di bawahnya.

Secara umum, siswa tampak aktif dan antusias dalam diskusi kelompok. Meskipun demikian, ada siswa yang terlihat kurang mampu menyampaikan pendapatnya. Hal ini dikarenakan mereka belum terbiasa bekerja dalam kelompok. Karena selama ini pembelajaran matematika dilakukan hanya terpusat pada guru dan belum pernah dilakukan dengan diskusi kelompok.

Dalam diskusi kelompok ini siswa berpikir bersama-sama untuk menyelesaikan LKS. Masing- masing siswa menyumbangkan pendapat mereka untuk mendapatkan konsep yang benar. Hal ini sesuai dengan pendapat Eggen \& Kauchack (2001) bahwa pemahaman siswa akan meningkat disebabkan adanya interaksi dalam kelompok. Tidak sedikit terjadi perdebatan diantara anggota kelompok untuk mempertahankan pendapat mereka. Beberapa siswa yang tidak mengerti masalah di dalam LKS dapat 
bertanya kepada temannya atau guru yang selalu memonitor jalannya diskusi. Guru berusaha memberikan bimbingan dan mengarahkan siswa melalui pertanyaan arahan yang dapat dikembangkan sendiri oleh siswa.

Tahap akhir adalah membuat kesimpulan hasil pembelajaran dan mengadakan pemantapan berupa latihan soal. Latihan soal dilakukan agar siswa tidak hanya dapat menemukan rumus tetapi dapat mengaplikasikan dalam menyelesaikan soal. Selanjutnya dilakukan tes akhir.

Berdasarkan hasil tes akhir siswa ada 34 siswa yang memperoleh nilai > 65 sedangkan 6 siswa memperoleh nilai $\leq 65$. Artinya dari skor hasil tes siswa $85 \%$ dari keseluruhan siswa telah memperoleh skor $>65$.

Dalam penelitian ini juga dilaksanakan tes akhir yang bertujuan untuk mengetahui penguasaan siswa terhadap konsep penggunaan luas daerah persegi panjang dalam kehidupan sehari-hari. Tes akhir ini dilaksanakan setelah siswa mengalami pembelajaran materi aplikasi luas persegi panjang. Berdasarkan skor hasil tes akhir didapatkan bahwa 40 siswa diperoleh bahwa 36 siswa memperoleh skor > 65 dan 4 siswa memperoleh skor $\leq 65$. Artinya dari skor hasil tes akhir siswa $90 \%$ dari keseluruhan siswa telah memperoleh skor $>65$. Dan rata-rata siswa secara klasikal untuk skor hasil tes akhir siswa adalah 85,125.

\section{Kesimpulan dan Saran}

Dari data-data yang diperoleh, peneliti membuat simpulan, bahwa: pembelajaran menurut standar NCTM yang dapat meningkatkan pemahaman luas persegi panjang siswa dengan langkah-langkah sebagai berikut:

1. Pertama, guru membagi siswa menjadi delapan kelompok yang heterogen berdasarkan akademik, gender, dan status sosial, kemudian guru menjelaskan tugas serta tanggung jawab anggota kelompok.

2. Kedua, guru menyampaikan tujuan dan indikator ketercapaian pembelajaran pada materi luas persegi panjang. Guru kemudian memberikan motivasi kepada siswa dengan menyampaikan manfaat luas persegi panjang pada kehidupan sehari-hari. Guru juga menanyakan pengetahuan awal tentang sifat- sifat persegi panjang sebagai pengetahuan prasyarat siswa dalam pembelajaran luas persegi panjang (wacana).

3. Ketiga, guru membagi LKS, LKS ini terdiri dari dua LKS. LKS 1 yang berisi soal-soal yang berkaitan dengan penemuan rumus luas persegi panjang dan LKS 2 berisi soal-soal yang berkaitan dengan aplikasi luas persegi panjang dalam kehidupan sehari-hari (Tugas).

4. Keempat, guru mempersilahkan siswa untuk melakukan diskusi kelompok. pada kegiatan ini, guru mengkondisikan lingkungan agar tercipta suasana yang kondusif dimana siswa secara aktif dapat mengkomunikasikan ide-ide dan pendapatnya (wacana dan lingkungan). Selain itu guru memonitor bagaimana baiknya tugas, wacana dan lingkungan yang telah tercipta didalam kelas untuk mempercepat perkembangan siswa(analisis).

5. Kelima, guru memberikan kesempatan kepada perwakilan dari kelompok untuk mempresentasikan hasil diskusinya dan mempersilahkan kepada kelompok lain untuk menanggapinya. Di akhir pembelajaran guru meminta siswa untuk membuat kesimpulan dari apa yang telah dipelajarinya. untuk mengetahui pemahaman siswa secara lebih mendalam dilakukan melalui tes akhir dan wawancara.

Selain itu, disimpulkan juga bahwa:

i. Siswa merasa senang dengan pembelajaran berdasarkan standar proses NCTM yang dapat meningkatkan pemahaman siswa.

ii. Media pembelajaran berupa gambar-gambar bangun datar persegi, segitiga, persegi panjang, dan lingkaran sangat diperlukan untuk membantu siswa dalam meningkatkan pemahaman terhadap konsep luas persegi panjang. 
Berdasarkan hasil penelitian ini, disarankan:

1. Guru matematika kelas 3 SD hendaknya dapat mempertimbangkan pembelajaran geometri dengan berdasarkan standar NCTM untuk membelajarkan materi luas daerah persegi panjang.

2. Sebelum membelajarkan siswa dengan standar NCTM, guru hendaknya memperhatikan pemahaman siswa terhadap materi prasyarat. Hal in akan mendukung kelancaran dan keberhasilan siswa dalam belajar, karena apabila siswa kurang memahami materi prasyarat akan menghambat dalam mengikuti pembelajaran.

3. Ketika guru menjumpai ada siswa yang pasif maka guru harus memberikan motivasi kepada siswa tersebut. Dan apabila ada siswa yang mendominasi suatu kelompok maka guru berperan untuk mengingatkan dan mengkondisikan agar siswa bisa bekerjasama dalam kelompok dan mengarahkan dengan cara yang baik kepada siswa yang mendominasi tadi.

4. Dalam proses pembelajaran, apabila dijumpai siswa yang kurang berani mengemukakan pendapatnya saat ditanya oleh guru, maka guru berperan untuk memotivasi siswa tersebut dan menyampaikan bahwa siswa tidak boleh takut salah.

5. Bagi peneliti lain yang berminat melakukan penelitian lanjutan, mereka dapat mengembangkan standar NCTM ini pada materi matematika yang lainnya sehingga akan diperoleh gambaran lebih lanjut mengenai efektivitas pembelajaran dengan berdasarkan standar NCTM.

\section{Referensi}

[1] Eggen, PD \& Kauchak, PP.. 1996. Strategies for Teacher: Teaching Content and Teaching Skill. Boston: Allyn \& Bacon.

[2] Elli Kusumawati. (2005). Pembelajaran Kubus dan Balok Menurut Standar Pengajaran NCTM dengan Setting Kooperatif pada Siswa Kelas I SMK Negeri I Batu. Tesis tidak dipublikasikan. PPs UM Malang

[3] Hudojo, H. (1998). Pembelajaran Matematika Menurut Pandangan Konstruktivis. Makalah ini disajikan pada Seminar Nasional Pendidikan Matematika, PPs IKIP Malang, 4 April 1998.

[4] Madja, M.S.. 1992. Perancangan dan Implementasi Perangkat Ajar Geometri SMTA. Tesis tidak diterbitkan. Jakarta: PPS UI.

[5] Miles dan Huberman, A.M.. 1992. Analisis Data Kualitatif. Terjemahan Oleh Tjetjep Rohendi Rohidi. Jakarta: UI Press.

[6] NCTM, 2000. Principles and Standards for School Mathematics. Reston, Virginia: The National Council of Teachers of Mathematics, Inc.

[7] Nu"man, Mulin. 2006. Pembelajaran Berdasarkan Tahap Berpikir van Hiele untuk Membantu Pemahaman Konsep Bangun Segiempat pada Siswa Kelas VII MTS Negeri Malang 1. Tesis tidak diterbitkan. Malang: PPS IKIP Malang.

[8] Orton. 1994. Learning Mathematics (Issues, Theory And Clasroom Practice). Cassell

[9] Ratumanan, T.G.. 2002. Belajar dan Pembelajaran. Surabaya: Unesa University Press

[10] Sholahudin, al"ayubi. 2005. Pembelajaran konsep luas persegi panjang dengan metode penemuan terbimbing pada siswa kelas IV SD AL Baitul amien (full day school) jember. Tesis tidak diterbitkan. Malang: PPS IKIP Malang.

[11] Sudarman. 2000. Pengembangan Peker Pembelajaran Berbantuan Komputer Materi Luas dan Keliling Segitiga untuk Kelas $V$ Sekolah Dasar. Tesis tidak diterbitkan. Malang: PPS UM.

[12] Sunismi, 2001. Diagnosis Kesulitan Siswa SLTP dalam Memahami Konsep Bangun Segiempat dan Remidinya. Tesis tidak diterbitkan. Malang: PPS UM.

[13] Susanto, 1997. Pembelajaran Persegi dan Persegipanjang dengan Pendekatan Keterampilan Bertanya pada Siswa Kelas 3 SD Laboratorium IKIP Malang. Tesis tidak diterbitkan. Malang: PPS IKIP Malang.

[14] Van de Walle, J.A.. 1990. Elementary School Mathematics: Teaching Developmentally. New York: Longman. 